\title{
Differences in Liver Folate Enzyme Patterns in Premature and Full Term Infants
}

\author{
AIDA KALNITSKY, DAVID ROSENBLATT, ${ }^{(19)}$ AND STANLEY ZLOTKIN \\ Medical Research Council Genetics Group and Center for Human Genetics, McGill University-Montreal Children's \\ Hospital Research Institute, Montreal, Quebec, Canada and Departments of Nutritional Sciences and Pediatrics, \\ Faculty of Medicine, University of Toronto, and Division of Clinical Nutrition, Research Institute, Hospital for Sick
} Children, Toronto, Ontario, Canada

\section{Summary}

The specific activities of four folate enzymes have been measured in livers from preterm infants (Group 1), full-term infants (Group 2), and from control subjects (Group 3). The four enzymes studied were methylenetetrahydrofolate reductase (EC 1.1.1.68), methionine synthetase (EC 2.1.1.13), methylenetetrahydrofolate dehydrogenase (EC 1.5.1.5), and glutamate formiminotransferase (EC 2.1.2.5). The specific activities for methylenetetrahydrofolate reductase were $6.62 \pm 0.51,4.42 \pm 0.31$, and $2.60 \pm 0.40$ (nmoles formaldehyde/mg protein/h, mean \pm S.E.) for groups 1,2 and 3 , respectively.

The specific activities for the three groups for methionine synthetase were $0.99 \pm 0.11,0.64 \pm 0.06$, and $0.42 \pm 0.05$ (nmoles methionine/mg protein/h, mean \pm S.E.). The specific activities for the three groups for glutamate formiminotransferase were $84.1 \pm$ $10.7,108.6 \pm 14.6$, and $104.3 \pm 17.8$ (nmoles methenyltetrahydrofolate/mg protein/min, mean \pm S.E.). The specific activities for the three groups for methylenetetrahydrofolate dehydrogenase were $0.16 \pm 0.03,0.39 \pm 0.07$, and $0.92 \pm 0.16$ (nmoles methenyltetrahydrofolate $/ \mathrm{mg}$ protein $/ \mathrm{min}$, mean \pm S.E.). During development, the specific activities of methylenetetrahydrofolate reductase and methionine synthetase decreased whereas the specific activity of methylenetetrahydrofolate dehydrogenase increased and that of glutamate formiminotransferase remained constant. In addition, the activities of methylenetetrahydrofolate reductase, methionine synthetase, and methylenetetrahydrofolate dehydrogenase were significantly influenced by postnatal age.

\section{Speculation}

Deficiency of two of the folate enzymes studied, methylenetetrahydrofolate reductase and glutamate formiminotransferase, are associated with genetic disorders. Knowledge of the developmental patterns of the folate enzymes in human liver may have important implications in the diagnosis and early treatment of these inborn errors of metabolism.
Reduced folates act as carriers of one-carbon units, which may be derived from serine, glycine, histidine, or from formate (6). These one-carbon units can be used in the synthesis of purines, pyrimidines and methionine. To date, deficiencies of five folate enzymes have been linked to inborn errors of metabolism. The enzymes are dihydrofolate reductase (EC 1.5.1.3), methenyltetrahydrofolate cyclohydrolase (EC 3.5.4.9), methylenetetrahydrofolate reductase (EC 1.1.1.68), methionine synthetase (EC 2.1.1.13), and glutamate formiminotransferase (EC 2.1.2.5) (2). At present, only two of these five enzymes have been demonstrated nonequivocally to be associated with inborn errors of folate metabolism: methylenetetrahydrofolate reductase and glutamate formiminotransferase (2).

Although at least one patient with severe methylenetetrahydrofolate reductase deficiency has responded to combined vitamin and methionine therapy (4), success with therapy of severely affected patients has not been universal (9); thus, the possibility exists that prenatal diagnosis of a deficiency of this enzyme may be important.

The present study attempts to examine the development of activity in preterm and full-term infants during the first year of life. The four folate enzymes studied are methylenetetrahydrofolate reductase, methionine synthetase, glutamate formiminotransferase, and methylenetetrahydrofolate dehydrogenase (EC 1.5.1.5).

\section{MATERIALS AND METHODS}

Liver samples were obtained during postmortem examination of infants free of liver disease, as previously described (15). Consent for each postmortem examination was received before autopsy. Samples from autopsies completed within $48 \mathrm{~h}$ of death were collected and immediately frozen. Samples were prepared and analyzed for cystathionase activity as previously reported (15). The remaining aliquots of liver were shipped frozen to Montreal where they were stored at $-70^{\circ} \mathrm{C}$ until preparation for

Table 1. Characteristics of each group of subjects

\begin{tabular}{|c|c|c|c|c|c|c|c|c|c|}
\hline \multirow[b]{2}{*}{$\begin{array}{l}\text { Group } \\
\text { number }\end{array}$} & \multicolumn{3}{|c|}{$\begin{array}{l}\text { Methylenetetrahydrofolate reductase and me- } \\
\text { thionine synthetase }\end{array}$} & \multicolumn{3}{|c|}{ Cystathionase } & \multicolumn{3}{|c|}{$\begin{array}{l}\text { Methylenetetrahydrofolate dehydrogenase } \\
\text { and glutamate formiminotransferase }\end{array}$} \\
\hline & 1 & 2 & 3 & 1 & 2 & 3 & 1 & 2 & 3 \\
\hline $\begin{array}{l}\text { Number of } \\
\text { subjects }\end{array}$ & 22 & 36 & 10 & 24 & 36 & 13 & 16 & 19 & 8 \\
\hline \multicolumn{10}{|l|}{$\begin{array}{l}\text { Gestational } \\
\text { age (wk) }\end{array}$} \\
\hline Range & $23-35$ & $37-41$ & & $23-36$ & $37-41$ & & $26-35$ & $37-41$ & \\
\hline Mean & $29.6 \pm 0.7^{1}$ & $39.5 \pm 0.2$ & & $29.9 \pm 0.7$ & $39.5 \pm 0.2$ & & $29.9 \pm 0.7$ & $39.3 \pm 0.2$ & \\
\hline \multicolumn{10}{|l|}{$\begin{array}{l}\text { Postnatal } \\
\quad \text { age (days) }\end{array}$} \\
\hline Range & $0.2-66$ & $0.2-300$ & $420-3468$ & $0.2-66$ & $0.2-300$ & $420-6570$ & $0.4-66$ & $0.5-240$ & $420-3468$ \\
\hline Mean & $6.8 \pm 3.1$ & $55.9 \pm 12.1$ & $2170 \pm 370$ & $6.7 \pm 2.8$ & $51.4 \pm 11.8$ & $2620 \pm 450$ & $6.6 \pm 4.0$ & $53.5 \pm 15.2$ & $1900 \pm 410$ \\
\hline
\end{tabular}


examination of the activity of the four folate enzymes. Cystathionase values for these samples have been previously reported (15) and serve for comparison with the four enzymes in this study.

For assay of the folate enzymes, liver samples (about $0.5 \mathrm{~g}$ ) were homogenized with 3 volumes of $0.25 \mathrm{M}$ sucrose and the homogenate centrifuged at $1085 \times g$ for $10 \mathrm{~min}$. The supernatant was next sonicated for $90 \mathrm{sec}(6 \times 15 \mathrm{sec})$ on ice with an ultrasonic disintegrator (16) and then centrifuged for $1 \mathrm{~h}$ at $27,000 \times$ $g$. The supernatant was removed and frozen in aliquots at $-20^{\circ} \mathrm{C}$.

Methylenetetrahydrofolate dehydrogenase was assayed according to the method of Tan et al. (14). Glutamate formiminotransferase was assayed according to the method of Drury and MacKenzie (1). Methionine synthetase was assayed according to
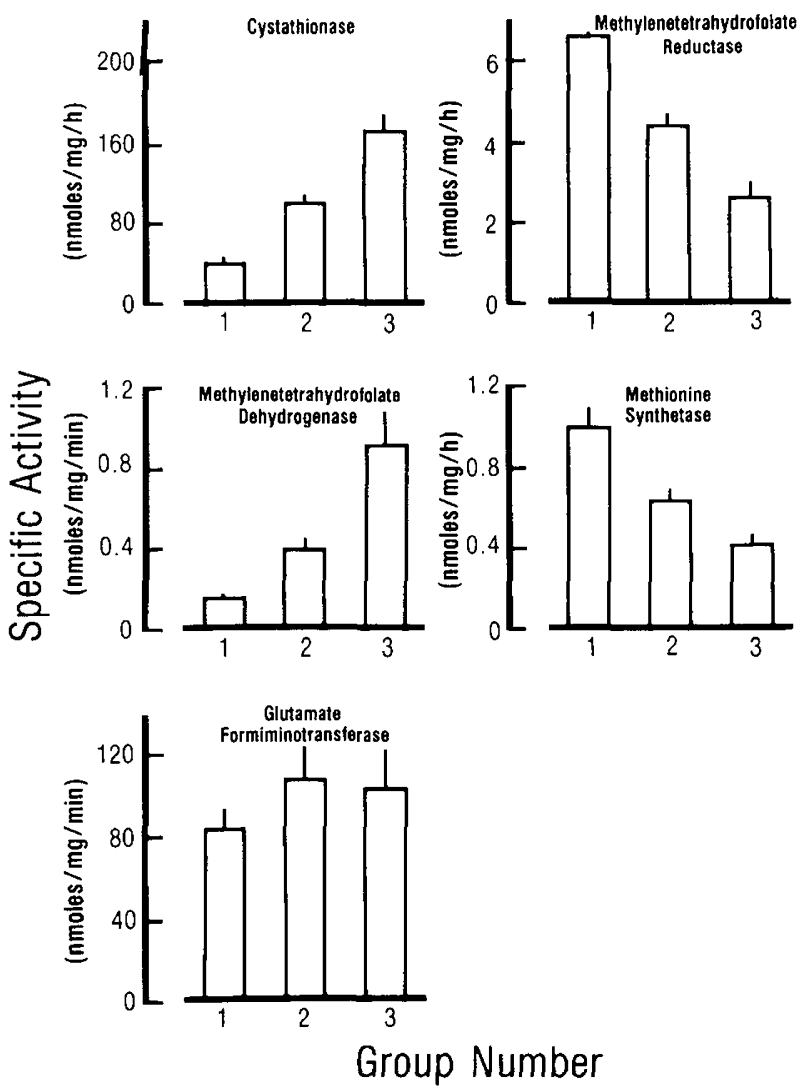

Fig. 1. Changes in liver folate enzyme activity during development. Group 1 consists of preterm infants, group 2 full-term infants, and group 3 individuals older than 1 year of age (as described in Table 1). Mean values are represented by the height of the bars and vertical lines indicate the mean \pm S.E. the method of Kamely et al. (5). Methylenetetrahydrofolate reductase was assayed as previously described (13). Protein concentrations were determined by the method of Lowry et al. (7) using human serum albumin as a standard.

\section{RESULTS}

The specific activities of four folate enzymes, methylenetetrahydrofolate reductase, methionine synthetase, methylenetetrahydrofolate dehydrogenase, and glutamate formiminotransferase, were measured in human liver. Cystathionase activity (15) was used as a control for comparison.

The liver samples were divided into three groups: preterm infants (Group 1), full-term infants (Group 2), and control subjects greater than 1 year of age (Group 3). The characteristics of each group are presented in Table 1 . Not all enzymes were assayed in each liver sample since not enough material was available.

Group means (Fig. 1) were determined for each of the four enzyme activities. A one-way analysis of variance followed by Duncan's new multiple-range test were used to test the significance of the difference between the means for each enzyme activity. There was a significant decrease (Table 2) in methylenetetrahydrofolate reductase activity with development whereas methionine synthetase activity decreased significantly only in full-term as compared to preterm infants. Methylenetetrahydrofolate dehydrogenase activity was greater in tissues from full-term than preterm infants and greater still in samples from the control group. The activity of glutamate formiminotransferase did not differ significantly between groups.

The data was analyzed by analysis of variance to determine whether the observed differences could be attributed to lability of the enzymes. The effect of postmortem delay, length of time that the liver tissue had been kept frozen at $-70^{\circ} \mathrm{C}$, and duration of freezing of the extract at $-20^{\circ} \mathrm{C}$ on group means for each of the four folate enzymes was determined. None of these factors appeared to significantly influence the results $(P>0.05)$.

Using the data for the full-term infants (Group 2), each of the folate enzyme activities was plotted as a function of postnatal age (Fig. 2). Methylenetetrahydrofolate reductase and methionine synthetase activities decreased with postnatal age. Methylenetetrahydrofolate dehydrogenase activity increased with postnatal age whereas glutamate formiminotransferase activity did not vary significantly with postnatal age.

\section{DISCUSSION}

We have thus measured the levels of four folate enzymes in liver tissue from preterm and full-term infants and from a control group. It appeared that during development the level of both methylenetetrahydrofolate reductase and methionine synthetase decreased whereas the activity of methylenetetrahydrofolate de-

Table 2. Comparison of group means for each enzyme studied

Specific activity

\begin{tabular}{|c|c|c|c|c|c|}
\hline & $\begin{array}{c}\text { Methylenetetrahydrofo- } \\
\text { late reductase (nmoles } \\
\text { formaldehyde } / \mathrm{mg} \text { pro- } \\
\text { tein } / \mathrm{h} \text { ) }\end{array}$ & $\begin{array}{c}\text { Methionine synthetase } \\
\text { (nmoles methionine/mg } \\
\text { protein } / \mathrm{h} \text { ) }\end{array}$ & $\begin{array}{l}\text { Cystathionase (nmoles } \\
\text { cysteine } / \mathrm{mg} \text { protein } / \mathrm{h} \text { ) }\end{array}$ & $\begin{array}{c}\text { Glutamate formimino- } \\
\text { trasferase (nmoles meth- } \\
\text { enyltetrahydrofolate } / \mathrm{mg} \\
\text { protein } / \mathrm{min} \text { ) }\end{array}$ & $\begin{array}{c}\text { Methylenetetrahydrofo- } \\
\text { late dehydrogenase } \\
\text { (nmoles methenyltetrah- } \\
\text { ydrofolate/mg protein/ } \\
\mathrm{min} \text { ) }\end{array}$ \\
\hline Group 1 & $6.62 \pm 0.51^{1}$ & $0.99 \pm 0.11$ & $39.6 \pm 5.1$ & $84.1 \pm 10.7$ & $0.16 \pm 0.03$ \\
\hline Group 2 & $4.42 \pm 0.31$ & $0.64 \pm 0.06$ & $99.3 \pm 8.2$ & $108.6 \pm 14.6$ & $0.39 \pm 0.07$ \\
\hline \multirow[t]{2}{*}{ Group 3} & $2.60 \pm 0.40$ & $0.42 \pm 0.05$ & $171.5 \pm 14.4$ & $104.3 \pm 17.8$ & $0.92 \pm 0.16$ \\
\hline & & & $P$ value ${ }^{2}$ & & \\
\hline Group 1 vs. 2 & $P<0.01$ & $P<0.01$ & $P<0.01$ & not significant & \\
\hline Group 2 vs 3 & $P<0.01$ & not significant & $P<0.01$ & not significant & $P>0.01$ \\
\hline Group 1 vs 3 & $P<0.01$ & $P<0.01$ & not significant & $P<0.01$ & $P<0.01$ \\
\hline
\end{tabular}

\footnotetext{
${ }^{1}$ Mean \pm S.E.
}

${ }^{2}$ The significance of the differences between group means was tested using a one-way analysis of variance followed by Duncan's new multiple-range test. 

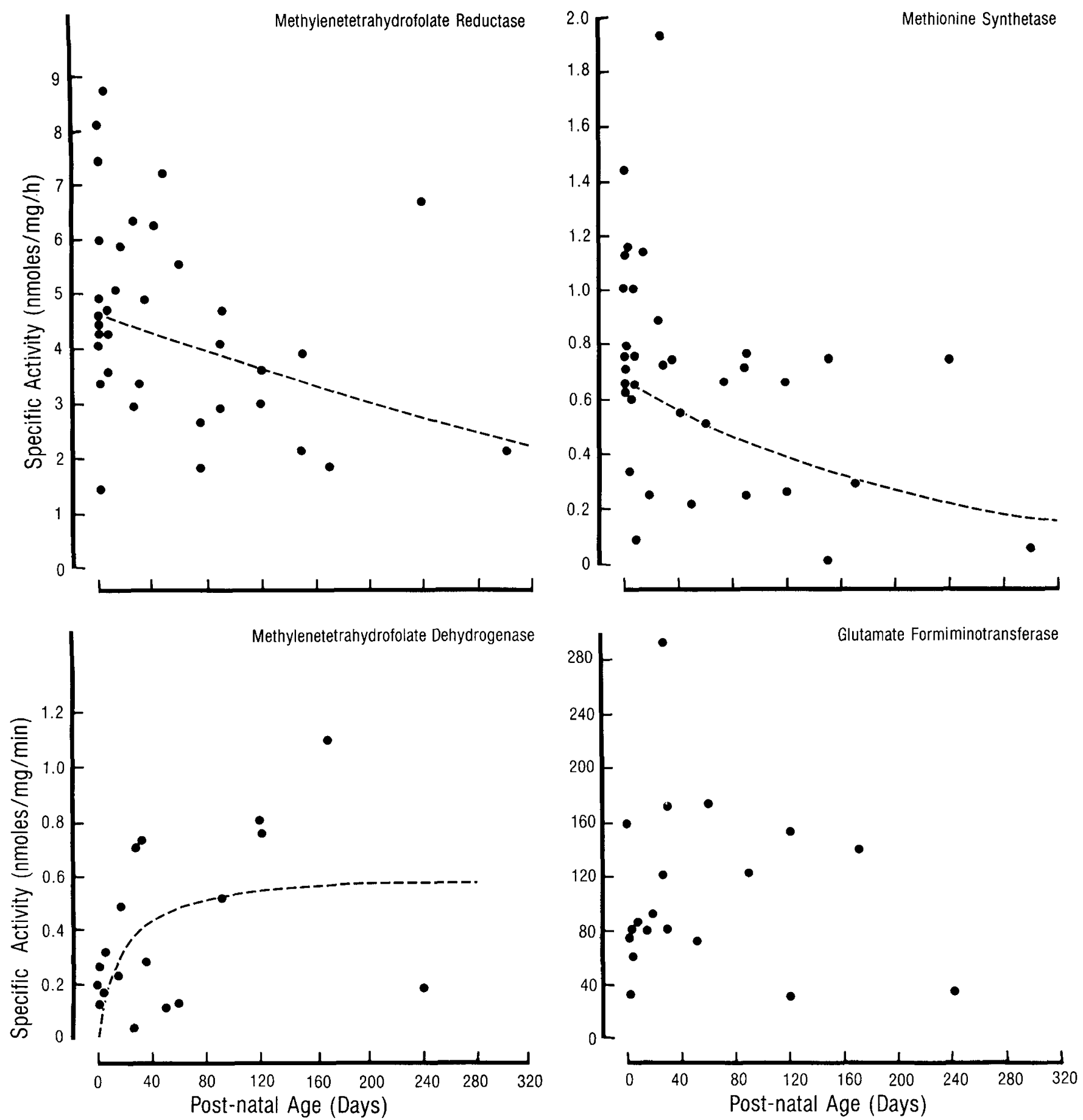

Fig. 2. Influence of postnatal age on liver folate enzyme levels in full-term infants. Each point represents an individual measurement. Where possible, a line has been fitted to the points to relate each enzyme activity to postnatal age. The correlation coefficients for the lines drawn are as follows: methylenetetrahydrofolate reductase, $r=0.33, P<0.05$; methionine synthetase, $r=0.43, P<0.01$; and methylenetetrahydrofolate dehydrogenase, $r=0.51, P<0.05$. There is no correlation $(P>0.05)$ between glutamate formiminotransferase activity and postnatal age.

hydrogenase increased and that of glutamate formiminotransferase remained constant. The differences in activities in the three groups could not be accounted for by postmortem delay or storage time of the livers or of the extracts.

Methylenetetrahydrofolate dehydrogenase has been described in porcine liver as being associated with both methylenetetrahydrofolate cyclohydrolase and formyltetrahydrofolate synthetase in a single polypeptide chain (14). Methylenetetrahydrofolate cyclohydrolase deficiency has been putatively linked to an inborn error of metabolism. Because this enzyme is difficult to measure in extracts of cultured human fibroblasts (2) we chose to measure the activity of the methylenetetrahydrofolate dehydrogenase in our liver extracts. We found the activity of this enzyme, like that of cystathionase (15), to increase during development.

Gaull et al. (3) have measured the levels of methionine synthetase in liver and brain from human fetuses. Similar to our results, the enzyme activity was found to be higher in second trimester fetal liver and brain than in mature liver and brain.

More recently, it has been found that the activities of two folatedependent enzymes involved in thymidine synthesis, dihydrofolate reductase, and thymidylate synthetase, was greatest in the cerebellum of the rat after birth and then decreased (8). A similar trend was observed for methylenetetrahydrofolate reductase activity. 
Serine hydroxymethyltransferase activity, also important for $d e$ novo DNA synthesis, has been found to be increased in fetal brain as compared to mature brain. It does not appear to change in the liver with development (3).

Of the four folate enzymes examined, methylenetetrahydrofolate reductase and glutamate formiminotransferase are associated with known autosomal recessive inborn errors of metabolism (2, 10). Glutamate formiminotransferase deficiency has been described in several families with variable clinical presentation ranging from severe neurologic abnormalities to virtually asymptomatic individuals (2). This enzyme is not present in cultured human fibroblasts making confirmation of the deficiency more difficult (2). Our studies show that glutamate formiminotransferase activity does not vary significantly with development. Methylenetetrahydrofolate reductase deficiency is characterized by homocystinuria and variable neurologic manifestations depending on the severity of the enzyme deficiency (11). At least one patient with severe deficiency has been shown to respond to dietary therapy with folate, vitamins $B_{12}$ and $B_{6}$, and methionine (4). At least three partially treated patients did not respond to vitamin therapy (12), but methionine supplementation was not attempted (9). The present study demonstrates that the level of methylenetetrahydrofolate reductase along with that of methionine synthetase is relatively high, at least in liver, in premature infants and falls after term. Because of the high activity of the methylenetetrahydrofolate reductase during early development it is possible that early diagnosis and treatment of this disorder is important. As yet, not enough children have been diagnosed early and treated to comment on the long term benefits of dietary and vitamin therapy.

\section{REFERENCES AND NOTES}

1. Drury, E. J. and MacKenzie, R. E.: Formiminotransferase-cyclodeaminase from porcine liver. A sulfhydryl essential for the deaminase activity of the bifunctional enzyme. Can. J. Biochem., 55: 919 (1977).

2. Erbe, R. W.: Genetic aspects of folate metabolism. In: H. Harris and K. Hirschhorn, Ed., Advances in Human Genetics, Vol. 9, p. 293 (Plenum Press, New York, 1977)

3. Gaull, G. E., Von Berg, W., Räihä, N. C. R., and Sturman, J. A.: Development of methyltransferase activities of human fetal tissues. Pediatr. Res., 7: 527 (1973).
4. Harpey, J. P., Rosenblatt, D. S., Cooper, B. A., Le Moël, G., Roy, C., and Lafourcade, $\mathbf{J}$.: Homocystinuria caused by 5,10 -methylenetetrahydrofolate reductase deficiency: a case in an infant responding to methionine, folinic acid, pyridoxine, and vitamin $\mathrm{B}_{12}$ therapy. J. Pediatr., 98: 275 (1981)

5. Kamely, D., Littlefield, J. W., and Erbe, R. W.: Regulation of 5-methylenetetrahydrofolate:homocysteine methyltransferase activity by methionine, vitamin $\mathrm{B}_{12}$, and folate in cultured baby hamster kidney cells. Proc. Natl. Acad. Sci., 70: 2585 (1973).

6. Krebs, H. A., Hems, R., and Tyler, B.: The regulation of folate and methionine metabolism. Biochem. J., 158: 341 (1976).

7. Lowry, O. H., Rosebrough, N. J., Fan, A. L., and Randall, R. J.: Protein measurement with the folin phenol reagent. J. Biol. Chem., 193: 265 (1951).

8. Mendible, J. C., Villarroel, O., Sanchez, C., and Ordonez, L. A.: Involvement of folate-dependent enzymes in thymidine synthesis during early rat brain development. Acta. Cient. Venezolana., 29: 389 (1978).

9. Narisawa, K., Wada, Y., Saito, T., Suzuki, H., Kudo, M., Arakawa, T., Katsushima, N., and Tsuboi, R.: Infantile type of homocystinuria with $\mathrm{N}^{5,10}$-methylenetetrahydrofolate reductase defect. Tohoku J. Exp. Med., 121: 185 (1977).

10. Niederweiser, A.: Inborn errors of pterin metabolism. In: M. I. Botez and E. H. Reynolds: Folic Acid in Neurology, Psychiatry, and Internal Medicine, p. 349 (New York, 1979).

11. Rosenblatt, D. S. and Cooper, B. A.: Methylenetetrahydrofolate reductase deficiency: Clinical and biochemical correlations. In: $M$. I. Botez and E. H. Reynolds: Folic Acid in Neurology, Psychiatry, and Internal Medicine, p. 385 (New York, 1979).

12. Rosenblatt, D. S., Cooper, B. A., Lue-Shing, S., Wong, P. W. K., Berlow, S. Narisawa, K., and Baumgartner, R.: Folate distribution in cultured human cells. J. Clin. Invest., 63: 1019 (1979).

13. Rosenblatt, D. S. and Erbe, R. W.: Methylenetetrahydrofolate reductase in cultured human cells. I. Growth and metabolic studies. Pediatr. Res., $11: 1137$ (1977).

14. Tan, L. U. L., Drury, E. J., and MacKenzie, R. E.: Methylenetetrahydrofolate dehydrogenase-methyltetrahydrofolate cyclohydrolase-formyltetrahydrofolate synthetase. A multifunctional protein from porcine liver. J. Biol. Chem., 252. 1117 (1977).

15. Zlotkin, S. H. and Anderson, G. H.: The development of cystathionase activity during the first year of life. Pediatr. Res. 16: 65 (1982).

16. MSE 100 watt Ultrasonic Disintegrator.

17. We gratefully acknowledge the technical assistance of Angela Pottier, Nora Vera Matiaszuk and Norie Churchill-Smith. We also wish to thank Dr. R. E. MacKenzie for this generous gift of tetrahydrofolic acid and Dr. D. E. C. Cole for his help with the statistical analysis.

18. This is publication number 81039 of the McGill University-Montreal Children's Hospital Research Institute.

19. Requests for reprints should be addressed to: Dr. D. S. Rosenblatt, MRC Genetics Group, Montreal's Children's Hospital, 2300 Tupper Street, Montreal, Quebec, Canada H3H 1 P3.

20. Received for publication August 27, 1981.

21. Accepted for publication February 11, 1982. 